\title{
ANALISIS PERCEPATAN TANAH PERMUKAAN DI WILAYAH RIAU DENGAN METODE PSHA
}

\author{
Elvis Saputra $^{1, *}$, Lalu Makrup ${ }^{2}$, Fitri Nugraheni ${ }^{3}$, Widodo $^{4}$ \\ ${ }^{1, *}{ }^{*}$ Magister Teknik Sipil, Fakultas Teknik Sipil dan Perencanaan, Universitas Islam Indonesia \\ Email: elvizsaputra95@gmail.com \\ ${ }^{2}$ Jurusan Teknik Sipil, Fakultas Teknik Sipil dan Perencanaan, Universitas Islam Indonesia \\ Email: lalu_makruf@yahoo.com \\ ${ }^{3}$ Jurusan Teknik Sipil, Fakultas Teknik Sipil dan Perencanaan, Universitas Islam Indonesia \\ Email: fitri.nugraheni@uii.ac.id \\ ${ }^{4}$ Jurusan Teknik Sipil, Fakultas Teknik Sipil dan Perencanaan, Universitas Islam Indonesia \\ Email:widodo355@gmail.com
}

\begin{abstract}
The western region of Sumatra Island is an area located on the world's active plate margin, which is reflected by the high frequency of earthquake events. An effort to reduce the impact of the earthquake disaster is to conduct a seismic hazard analysis. There have been many studies on seismic hazard in the West Sumatra region. Still, in the surrounding areas such as Riau, which borders directly with the territory, there has never been an earthquake hazard mapping micro zonation. This study aims to determine the value of surface acceleration for various districts or cities in Riau Province, by knowing the amount of surface acceleration, it will be able to identify the areas that have a relatively high level of earthquake risk. The Surface acceleration analysis is done by using the probabilistic Seismic hazard method (PSHA) using The SR Model software. The results of this study are obtained from 12 districts or cities located in Riau in which three areas have a high value of surface acceleration, those are Rokan Hulu regency, Kampar regency), and Kuantan Singingi regency). The amount of surface acceleration in Riau province in the 0.0 second period or peak ground acceleration (PGA) is in the range $0.097-0.78 \mathrm{~g}$, then in the 0.2 second period the surface acceleration is in the range $0.204-1.943 \mathrm{~g}$, and in the 1 second period of the surface acceleration is in the range $0.176-1.155 \mathrm{~g}$.
\end{abstract}

Keywords: Seismic hazard, probabilistic seismic hazard analysis (PSHA), surface acceleration

\section{PENDAHULUAN}

\section{Latar Belakang}

Wilayah barat pulau Sumatera merupakan salah satu kawasan yang terletak pada pinggiran lempeng aktif (active plate margin) dunia yang dicerminkan dengan tingginya frekuensi kejadian gempa bumi (Rohadi, 2008). Berdasarkan data historis kejadian gempa, telah terjadi beberapa gempa merusak salah satu diantaranya adalah gempa Padang tepatnya pada tanggal 30 September 2009 yang berdampak pada 13 kabupaten dan menelan korban jiwa lebih dari 1.100 orang (BNPB, 2009).

Berbagai upaya untuk mengurangi dampak dari bencana gempa telah banyak dilakukan oleh para peneliti salah satunya adalah dengan melakukan penelitian sismic hazard. Penelitian-penelitian tentang seismic hazard yang memuat wilayah Sumatera Barat telah banyak dilakukan, salah satunya adalah (Delfebriyadi, 2010) yang melakukan pengukuran respon spektra, tetapi untuk wilayah sekitarnya seperti Riau yang berbatasan langsung dengan wilayah tersebut belum pernah dilakukan pemetaan 
mikrozonasi bahaya gempa. Secara umum wilayah Riau dikelompokkan dalam kategori aktivitas seismik rendah, tetapi kategori tersebut tidak bisa mewakili semua kabupaten dan kota yang ada di Riau untuk wilayahwilayah yang berada tidak jauh dari perbatasan antara Sumatera Barat-Riau, pada saat terjadi gempa akan berpotensi mengalami getaran tanah yang cukup kuat. Dengan dilakukannya penelitian seismic hazard, maka potensi gempa bumi yang dicerminkan pada besaran nilai percepatan tanah pada daerah tertentu akan dapat diketahui.

Tahun 2017 Kementrian Pekerjaan Umum dan Perumahan Rakyat (KemenPUPR) telah merilis Peta Gempa Tahun 2017 yang disusun oleh Tim Pusat Studi Gempa Nasional (PuSGeN) untuk berbagai kota di Indonesia. Hasil dari peta tersebut ditemukan bahwa terdapat banyak sesar aktif yang muncul diberbagai wilayah di Indonesia. Sebelumnya pada peta gempa 2010 hanya terdapat 81 sesar aktif, tetapi pada peta gempa 2017 terdapat sebanyak 295 sesar aktif. Untuk sesar pulau Sumatera pada peta gempa 2010 hanya dibagi menjadi 19 segmen sesar, tetapi pada tahun 2017 terbagi menjadi 55 segmen sesar (PuSGeN, 2017). Dengan teridentifikasi banyaknya sesar aktif baru, maka akan berpotensi terjadinya peningkatan aktivitas gempa bumi di Indonesia.

Penelitian ini bertujuan untuk menentukan nilai percepatan tanah di permukaan untuk berbagai kabupaten atau kota di Provinsi
Riau. Setelah diperoleh nilai percepatan tanah, maka dapat diidentifkasi kabupatenkabupaten yang memiliki tingkat risiko gempa cukup tinggi. Hasil dari penelitian ini diharapkan dapat dijadikan pedoman dalam merencanakan pola tata ruang di Provinsi Riau.

\section{Ground Motion Prediction Equation (GMPE)}

Ground motion prediction equation adalah proses atau rumusan suatu gerakan baik berupa percepatan, kecepatan, simpangan, dan intensitas gempa yang akan mengecil pada jarak yang semakin menjauh dari sumber gempa. Persamaan GMPE secara umum mempresentasikan fungsi-fungsi yang terkait dengan informasi sumber gempa, jalur penjalaran gelombang gempa, dan kondisi lokasi titik pengamatan (Widodo, 2012).

Penentuan nilai percepatan tanah permukaan pada metode PSHA Permukaan dilakukan dengan cara sama seperti pada analisis PSHA di batuan dasar, yang berbeda pada analisis ini adalah penggunaan persamaan GMPE, pada PSHA batuan basar persamaan GMPE yang digunakan adalah GMPE khusus untuk batuan dasar dan begitu juga pada PSHA permukaan, GMPE yang digunakan juga khusus untuk analisis permukaan. Persamaan (1) samapai dengan persamaan (5) berikut ini merupakan persamaan GMPE yang digunakan dalam analisis tiap sumber gempa.

Sumber Gempa Subduksi (Douglas, 2018):

1. GMPE Youngs et al., (1997) $\ln y=-0.6687+1.438 M+\mathrm{C}_{1}+\mathrm{C}_{2}(10+M)^{3}-\mathrm{C}_{3} \ln \left(r_{r u p}+1.097 e^{0.554 M}\right)+0.00648 D+0.3643 Z_{T}$

2. GMPE Atkinson - Boore (2003) $\log y=f n(M)+C_{3} D+C_{4} . D-g \log R+C_{5} s l S_{C}+C_{6} s l S_{D}+C_{7} s l S_{E}$

Sumber Gempa Sesar (Douglas, 2018):

1. GMPE Sadigh et al (1997)

$$
\ln y=C_{1}+C_{2} M+C_{3} \ln \left[R_{r u p}+C_{4} e^{(C S M)}\right]+C_{6}+C_{7}(8.5-M)^{2.5}
$$

2. GMPE Boore-Atkinson (2006) NGA

$$
\text { ln } y=F_{M}(M)+F_{D}\left(R_{j b}, M\right)+F_{S}\left(V_{S 30}, R_{j b}, M\right)+\varepsilon \sigma_{T}
$$

3. GMPE Chiou-Youngs 2008 NGA

$$
\begin{array}{cc}
\ln \left(\mathrm{SA}_{\mathrm{ij}}\right)= & \ln \left(S A_{1130 i j}\right)+\phi_{1}\left[\ln \left(V s 30_{i j} / 1130\right), 0\right]_{\min }+\phi_{2}\left[\exp \left\{\phi_{2}\left(\left(V s 30_{i j}, 1130\right)_{\min }-360\right)\right\}-\exp \left\{\phi_{2}(1130-360)\right\}\right] \\
\left.\left.\ln \left[S A_{1130 i j}\right)+\phi_{4}\right) / \phi_{4}\right]+\sigma D_{i j} & (5)
\end{array}
$$




\section{Sumber Gempa}

Mekanisme sumber gempa tergantung pada kondisi tektonik. Pada penelitian ini digunakan dua tipe mekanisme gempa yaitu sumber gempa sesar/patahan dan sumber gempa subduksi. Segmen yang akan dibahas lebih lanjut adalah segmen yang masuk dalam cakupan jarak $500 \mathrm{~km}$ dari batas administrasi Provinsi Riau untuk sumber gempa subduksi dan $200 \mathrm{~km}$ untuk sumber gempa sesar. Jarak tersebut ditetapkan berdasarkan jangkauan analisis maksimum dari persamaan GMPE yang digunakan untuk memprediksi gerakan tanah. Sumber gempa yang masuk dalam cakupan jarak di atas dapat dilihat pada Tabel 1 dan Tabel 2.

Tabel 1. Segmen megathrust Sumatera

(PuSGeN, 2017).

\begin{tabular}{|l|c|c|c|c|}
\hline Segment Megathrust & $\begin{array}{c}L \\
(\mathrm{~km})\end{array}$ & $\begin{array}{c}W \\
(\mathrm{~km})\end{array}$ & $\begin{array}{c}\text { Sliprate } \\
(\mathrm{mm} / \mathrm{th})\end{array}$ & $M_{\max }$ \\
\hline Nias-Simelue & 400 & 200 & 4,0 & 8,9 \\
\hline Batu & 70 & 100 & 4,0 & 8,2 \\
\hline Mentawai-Siberut & 200 & 200 & 4,0 & 8,7 \\
\hline Mentawai-Pagai & 400 & 200 & 4,0 & 8,9 \\
\hline
\end{tabular}

Tabel 2. Segmen sesar Sumatera (PuSGeN, 2017).

\begin{tabular}{|c|c|c|c|c|c|c|c|}
\hline Segment & $\begin{array}{l}\text { Slipr } \\
\text { ate }\end{array}$ & $\begin{array}{l}\text { Mecha } \\
\text { nism }\end{array}$ & $\begin{array}{l}D \\
(9)\end{array}$ & $T$ & $B$ & $L$ & $M_{\text {ma: }}$ \\
\hline Renun A & 10,5 & $\begin{array}{c}\text { Strike- } \\
\text { slip }\end{array}$ & 90 & 3 & 20 & $\begin{array}{l}18 \\
0\end{array}$ & 7,7 \\
\hline Renun B & 8,0 & $\begin{array}{c}\text { Strike- } \\
\text { slip }\end{array}$ & 90 & 3 & 20 & 31 & 6,8 \\
\hline Renun C & 8,0 & $\begin{array}{c}\text { Strike- } \\
\text { slip }\end{array}$ & 90 & 3 & 20 & 26 & 6,7 \\
\hline Angkola & 6,0 & $\begin{array}{c}\text { Strike- } \\
\text { slip }\end{array}$ & 90 & 3 & 20 & $\begin{array}{l}16 \\
0\end{array}$ & 7,7 \\
\hline Barumun & 6,5 & $\begin{array}{l}\text { Strike- } \\
\text { slip }\end{array}$ & 90 & 3 & 20 & $\begin{array}{l}22 \\
5\end{array}$ & 7,5 \\
\hline Sianok & 14 & $\begin{array}{c}\text { Strike- } \\
\text { slip }\end{array}$ & 90 & 3 & 20 & 90 & 7,4 \\
\hline Sumani & 14 & $\begin{array}{c}\text { Strike- } \\
\text { slip }\end{array}$ & 90 & 3 & 20 & 60 & 7,1 \\
\hline Suliti & 14 & $\begin{array}{l}\text { Strike- } \\
\text { slip }\end{array}$ & 90 & 3 & 20 & 95 & 7,4 \\
\hline Siulak & 14 & $\begin{array}{c}\text { Strike- } \\
\text { slip }\end{array}$ & 90 & 3 & 20 & 70 & 7,2 \\
\hline Dikit & 12 & $\begin{array}{l}\text { Strike- } \\
\text { slip }\end{array}$ & 90 & 3 & 20 & 60 & 7,1 \\
\hline Ketun & 12 & $\begin{array}{l}\text { Strike- } \\
\text { slip }\end{array}$ & 90 & 3 & 20 & 85 & 7,3 \\
\hline Musi & 13,5 & $\begin{array}{l}\text { Strike- } \\
\text { slip }\end{array}$ & 90 & 3 & 20 & 70 & 7,2 \\
\hline \multicolumn{8}{|c|}{$\begin{array}{l}\mathrm{D}=\text { Dip }\left({ }^{\circ}\right), \mathrm{T}=\text { Top }, \mathrm{B}=\text { Bottom, } \mathrm{L}=\text { Panjang }(\mathrm{km}) \text {, dan } \\
\mathrm{M}=\text { Magnitude }\end{array}$} \\
\hline
\end{tabular}

\section{Probabilistic Seismic Hazard Analysis (PSHA)}

Peristiwa gempa bumi merupakan bagian dari gejala alam yang bersifat acak dan tidak dapat ditentukan dengan pasti, baik itu tempat kajadian, waktu kejadian, dan bersaran magnitude. Dengan menggunakan konsep probabilitas maka kejadian gempa dengan intensitas dan probabilitas tertentu dapat diperkirakan (Suku, 2014). Konsep probabilitas dalam analisis seismic hazard dikenal istilah Probabilistic Seismic Hazard Analysis (PSHA). Dengan metode PSHA ketidakpastian dalam menentukan parameterparameter gempa seperti magnitude maksimum, pemiihan persamaan GMPE, pemilihan model (recurrence model), dan reccurence rate ikut diperhitungkan dengan cara menerapkan konsep logic tree (Widodo, 2018). Tahapan analisis probabilistik dalam menentukan Peak Ground Acceleration (PGA) disajikan pada Gambar 1, Gambar 2 dan Gambar 3.
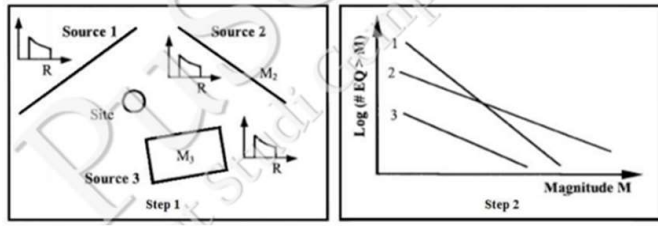

Gambar 1. Indentifikasi sumber gempa (step 1); dan menghitung parameter seisimic (step 2) (PuSGeN, 2017).

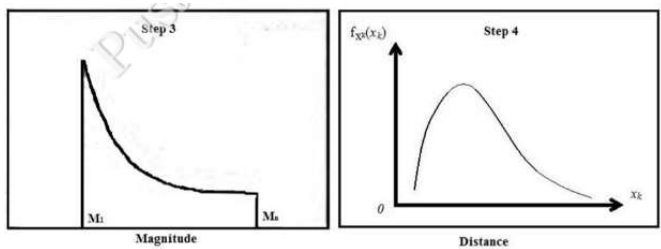

Gambar 2. Menghitung probabilitas magnitude (step 3); dan menghitung distribusi probabilitas jarak (step 4)

(PuSGeN, 2017). 


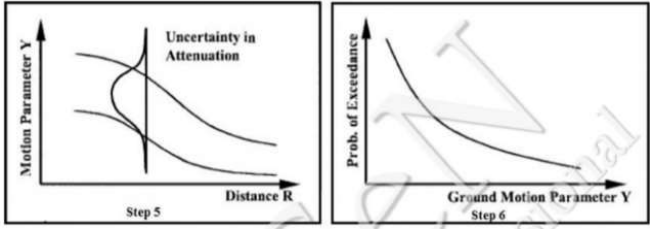

Gambar 3. Menghitung percepatan maksimum dengan berbagai magnitude (step 5); dan menghitung ketidakpastian kejadian gempa, besaran, dan predisksi percepatan max (step 6) (PuSGeN, 2017).
Dengan menggunakan konsep probabilitas total, kemungkinan parameter $X$ melampaui satu nilai $x$ tertentu, diberikan dalam bentuk integrasi dalam keseluruhan rentang magnitude dan jarak untuk rentang waktu yang ditinjau dan dinyatakan dalam persamaan (6) (Makrup, 2013) berikut.

$$
P x(x)=v \int_{M} \int_{R} P[X>x \mid m, r] f_{M}(m) f_{R}(r) d r d m
$$

dengan:

$P_{X}(x) \quad=$ probabilitas total dari suatu gempa yang menghasilkan percepatan puncak $X$ $>x$, magnitude $M$, jarak $R$ selama rentang waktu yang ditinjau,

$f_{M} \quad=$ fungsi probabilitas magnitude,

$f_{R} \quad=$ fungsi probabilitas jarak,

$P(X>x \mid m, r)=$ probabilitas sebuah gempa dengan magnitude $\mathrm{m}$ pada jarak $r$ yang memberikan percepatan maksimum $X$ di lokasi lebih tinggi dari $x$.

\section{METODOLOGI PENELITIAN}

\section{Pengumpulan Data Gempa}

Data yang digunakan pada penelitian ini adalah data historis kejadian gempa dari tahun 1963 sampai tahun 2019 yang diperoleh dari USGS dengan luas wilayah pengambilan dibatasi pada radius $200 \mathrm{~km}$ dari batas administrasi Provinsi Riau atau wilayah dengan batas koordinat 97.02 BT -103.023 BT dan -3.90 LS - 2.96 LS. Ketentuan data yang digunakan adalah data kejadian gempa dengan magnitude minimal 5 dan kedalaman maksimum $300 \mathrm{~km}$.

\section{Pengolahan Data Gempa}

Data kejadian gempa yang diperoleh atau dikumpulkan dari USGS memiliki skala magnitude yang berbeda. Skala magnitude yang diperoleh antara lain adalah surface wave magnitude $\left(\mathrm{M}_{\mathrm{S}}\right)$, Richter local magnitude $\left(\mathrm{M}_{\mathrm{L}}\right)$, body wave magnitude $\left(\mathrm{M}_{\mathrm{b}}\right)$, dan moment magnitude $\left(\mathrm{M}_{\mathrm{W}}\right)$. Untuk menjamin konsistensi dalam analisis kegempaan, maka digunakan skala magnitude yang sama yaitu Magnitude momen $\left(\mathrm{M}_{\mathrm{w}}\right)$, karena lebih konsisten dibandingkan dengan skala yang lain.
Data gempa yang telah dikonversi menjadi satu skala magnitude (Magnitude momen) selanjutnya dilakukan declustring yaitu pemisahan gempa dependen dan indenpenden. Selanjutnya kejadian gempa dependen dimasukkan ke dalam analisis akan mengakibatkan sedikit peningkatan hasil pada analisis seismic hazard (Makrup, 2013). Metode pemisahan gempa dependen dan independen dalam penelitin ini digunakan model empirik dari (Gardner dan Knopoff, 1974) dan dalam proses pemisahan digunakan bantuan software ZMAP Ver. 6 (Wiemer, 2001).

\section{Analisis Probabilistik (PSHA)}

Penentuan nilai percepatan tanah pada analisis PSHA digunakan bantuan software Seismik Risk Model (SR Model). Pada software SR-Model, berbagai ketidakapastian parameter gempa seperti ketidakpastian dari lokasi gempa, ukuran magnitude gempa, dan prediksi parameter gerakan tanah terlampaui pada periode tertentu akan dikombinasikan (Makrup, 2009). Luaran dari analisis SRModel berupa nilai percepatan di batuan dasar dan di permukaan tanah pada periode (PGA, 0.2 detik, dan 1 detik) dengan probabilitas terlampaui $2 \%$ dalam 50 tahun. 


\section{HASIL DAN PEMBAHASAN}

\section{Konversi Magnitude}

Hasil dari konversi magnitude diperoleh jumlah data gempa dengan ukuran magnitude $\left(\mathrm{M}_{\mathrm{W}}\right) \geq 5$ dan kedalaman pusat gempa kurang $<300 \mathrm{~km}$ sebanyak 825 kejadian gempa. Distribusi magnitude gempa yang masuk kedalam wilayah administrasi Provinsi Riau memang cukup sedikit seperti yang disajikan pada Gambar 4, tetapi jika dilihat di bagian Barat Riau tepatnya di Sumatera Barat sangat banyak terdapat distribusi kejadian gempa, sehingga pada kabupaten/kota di bagian Barat Provinsi Riau akan memiliki pengaruh yang cukup besar akibat gempa yang terjadi Sumatera Barat.

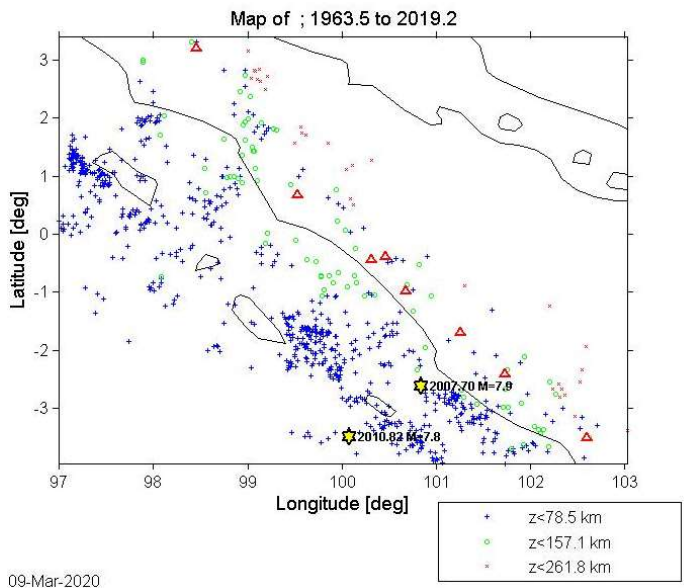

Gambar 4. Distribusi data gempa dengan $\mathrm{M}_{\mathrm{W}} \geq 5$ dan $\mathrm{D}<300 \mathrm{~km}$

\section{Pemisahan Gempa Dependen dan Independen}

Proses pemisahan gempa dependen dan independen berdasarkan rentang waktu dan jarak tertentu dari suatu kejadian gempa dalam penelitian mengacu pada metode empiris dari (Gardner and Knopoff, 1974). Setelah dilakukan pemisahan, jumlah kejadian gempa independen yang terdapat dari tahun 1963-2019 adalah 134 kejadian atau sebanyak 691 kejadian gempa dependen yang teridentifikasi.

\section{Pemodelan Sumber Gempa}

Pemodelan sumber gempa dapat dilakukan dengan melakukan interpretasi terhadap kondisi seismotektonik, geologi, dan geofisika berdasarkan katalog kejadian gempa dan juga mengacu pada penelitian terdahulu (Sunardi, 2013). Pemodelan sumber gempa meliputi sumber gempa shallow crustal dan subduksi. Kemudian sumber gempa subduksi dibagi menjadi 2 zona yaitu zona megathrust dan zona Benioff (Gambar $5)$.

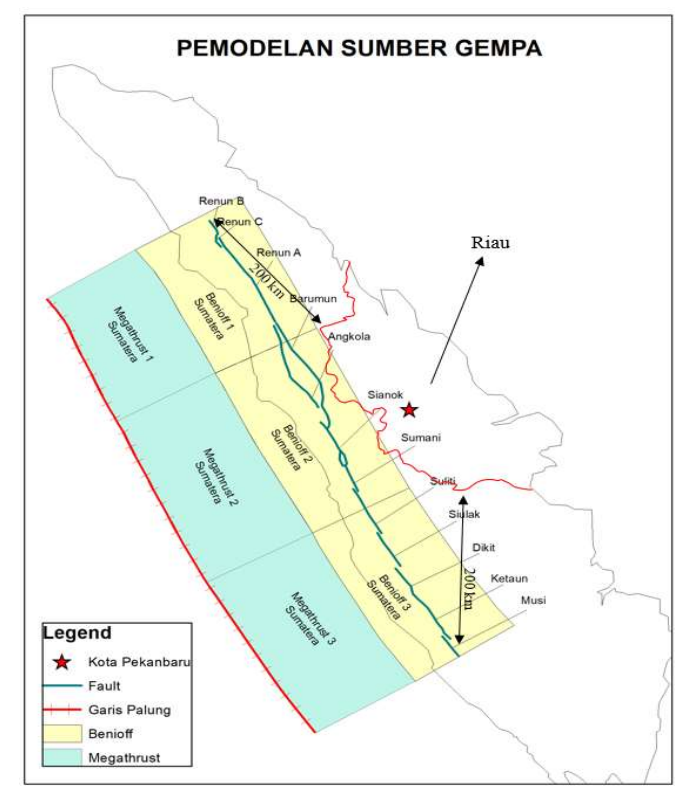

Gambar 5. Model sumber gempa

Dalam pemodelan sumber gempa 3 dimensi dibutuhkan data sudut penunjaman (dip) zona subduksi. Sudut penujaman tersebut dapat diidentifikasi berdasarkan potongan melintang distribusi hiposenter disekitar area yang ditinjau (Sunardi, 2013). Sudut penunjaman dalam pemodelan ini disajikan dalam Tabel 3.

Tabel 3. Rekapitulasi sudut penunjaman pada tiga zona subduksi

\begin{tabular}{|c|c|c|c|}
\hline \multirow{2}{*}{ No. } & \multirow{2}{*}{ Potongan } & \multicolumn{2}{|c|}{ Sudut Panunjaman } \\
\cline { 3 - 4 } & & Megathrust & Benioff \\
\hline 1 & Potongan Melintang 1 & $12^{\circ}$ & $36^{\circ}$ \\
\hline 2 & Potongan Melintang 2 & $12^{\circ}$ & $40^{\circ}$ \\
\hline 3 & Potongan Melintang 3 & $13^{\circ}$ & $36^{\circ}$ \\
\hline
\end{tabular}




\section{Karakteristik Sumber Gempa}

Karakteristik pada masing-masing sumber gempa tercermin dalam penentuan nilai- $a$, nilai- $b$, magnitude maksimum, dan slip-rate (Makrup, 2013). Nilai- $a$ yang besar mengindikasikan tingginya tingkat seismisitas dan nilai- $b$ yang besar mengindikasikan jumlah kejadian gempa dengan magnitude besar sedikit (Thant, 2008). Penentuan parameter nilai- $a$ dan nilai- $b$ dalam penelitian ini dianalisis menggunakan metode maximum likelihood (Aki, 1965), dengan menggunakan bantuan program ZMAP (Wiemer, 2001). Kemudian penentuan magnitude maksimum pada zona subduksi dan nilai slip-rate untuk tiap-tiap sumber gempa shallow crustal, mengacu pada hasil penelitian dari Tim Pusat Studi Gempa Nasional (PuSGeN, 2017). Karakteristik sumber gempa yang diperoleh dalam penelitian ini disajikan dalam Tabel 4 dan Tabel 5.

Tabel 4. Karakteristik sumber gempa subduksi

\begin{tabular}{|l|c|c|c|c|}
\hline \multicolumn{1}{|c|}{ Zona } & $\begin{array}{c}\text { Nilai } \\
\mathrm{a}\end{array}$ & $\begin{array}{c}\text { Nilai } \\
\mathrm{b}\end{array}$ & $\begin{array}{c}\text { Rate } \\
\mathrm{v}\end{array}$ & $\mathrm{M}_{\max }$ \\
\hline Megathrust 1 & 5.98 & 1.1 & 3.02 & 8,9 \\
\hline Benioff 1 & 8.69 & 1.62 & 3.89 & 8,9 \\
\hline Megathrust 2 & 6.55 & 1.2 & 3.55 & 8,7 \\
\hline Benioff 2 & 6.71 & 1.28 & 2.04 & 8,7 \\
\hline Megathrust 3 & 5.36 & 0.981 & 2.85 & 8,9 \\
\hline Benioff 3 & 7.4 & 1.4 & 2.51 & 8,9 \\
\hline
\end{tabular}

Tabel 5. Karakteristik sumber gempa fault

\begin{tabular}{|l|c|c|c|c|c|}
\hline Segmen & $\begin{array}{c}\text { Slip } \\
\text { Rate }\end{array}$ & $\begin{array}{c}\text { Nilai } \\
\mathrm{b}\end{array}$ & $\begin{array}{c}\text { Nilai } \\
\mathrm{a}\end{array}$ & $\begin{array}{c}\text { Rate } \\
\mathrm{v}\end{array}$ & $\mathrm{M}_{\max }$ \\
\hline Renun A & 10.5 & 1 & 4.92 & 0.83 & 7.4 \\
\hline Renun B & 8 & 1 & 4.81 & 0.65 & 6.8 \\
\hline Renun C & 8 & 1 & 4.59 & 0.39 & 6.7 \\
\hline Barumun & 6 & 1 & 4.57 & 0.37 & 7.7 \\
\hline Angkola & 6.5 & 1 & 4.62 & 0.42 & 7.5 \\
\hline Sianok & 14 & 1 & 4.62 & 0.42 & 7.4 \\
\hline Sumani & 14 & 1 & 4.94 & 0.87 & 7.1 \\
\hline Suliti & 14 & 1 & 4.88 & 0.77 & 7.4 \\
\hline Siulak & 14 & 1 & 4.94 & 0.87 & 7.2 \\
\hline Dikit & 12 & 1 & 4.90 & 0.80 & 7.1 \\
\hline Ketaun & 12 & 1 & 4.82 & 0.66 & 7.3 \\
\hline Musi & 13.5 & 1 & 4.85 & 0.71 & 7.2 \\
\hline
\end{tabular}

\section{Hasil Analisis Seimic Hazard (Peta Mikrozonasi)}

Percepatan gerakan tanah dipengaruhi oleh kontribusi dari masing-masing sumber gempa. Nilai percepatan tanah akan semakin mengecil seiring dengan bertambahnya jarak dari sumber gempa (Hadi, 2015).

Pengaruh besarnya nilai percepatan puncak di permukaan akibat sumber gempa sesar berasal dari Sesar Sumatera yang dilalui segmen Renun, Barumun, Angkola, Sianok, Sumani, Suliti, Siulak, Dikit, Ketaun dan Musi. Kemudian pengaruh besarnya nilai percepatan puncak di permukaan akibat sumber gempa subduksi berasal dari Megathrust Sumatera yang dilalui Segmen Nias-Simelue, Batu, Mentawai-Siberut dan Mentawai-Pagai.

Peta percepatan tanah puncak (PGA) menggambarkan percepatan tanah di permukaan sedangkan peta percepatan tanah spektra 0.2 detik dan 1 detik menggambarkan percepatan guncangan gempa bumi yang dialami oleh bangunan atau gedung dengan jumlah lantai lebih dari satu lantai (Badan Geologi, 2018). Hasil dari analisis seismic hazard (PSHA) dengan bantuan SR-Model yang memperhitungkan semua kontribusi sumber gempa di Provinsi Riau dapat dilihat pada Gambar 6, Gambar 7, dan Gambar 8. Hasil analisis menunjukkan bahwa nilai percepatan yang paling tinggi terdapat pada kabupaten yang memiliki jarak paling dekat dengan jalur Sesar Sumatera, sedangkan kabupaten-kabupaten yang memiliki jarak jauh dari jalur Sesar Sumatera, besar nilai percepatan terus berkurang seiring dengan bertambahanya jarak.

Hasil analisis menunjukkan bahwa nilai percepatan tanah dengan metode PSHA permukaan untuk probabilitas terlampaui $2 \%$ dalam 50 tahun menunjukkan hasil bahwa nilai percepatan tanah permukaan di provinsi Riau pada percepatan tanah puncak (PGA) berada pada rentang $0.097-0,780 \mathrm{~g}$. Percepatan tanah puncak di sekitar garis Sesar Sumatera memiliki nilai percepatan puncak sebesar $(0.6-0.78 \mathrm{~g})$ dan cenderung terus mengecil seiring bertambahnya jarak. 


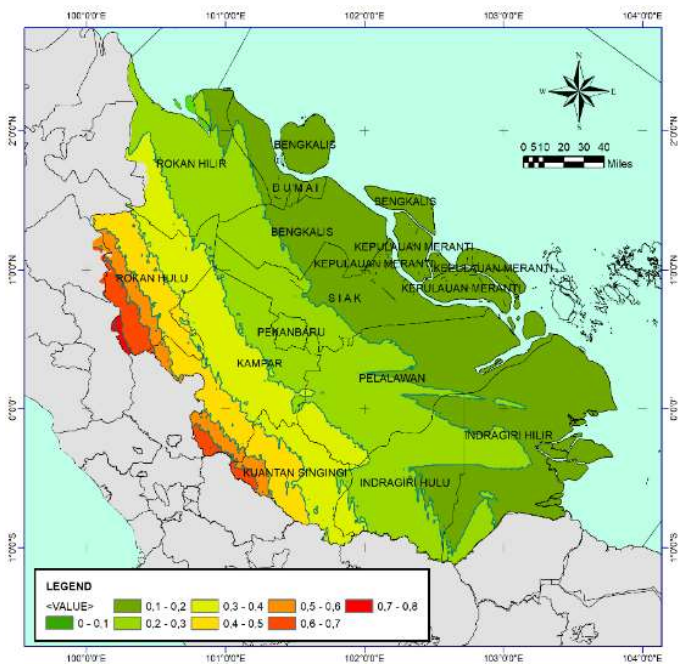

Gambar 6. Peta percepatan tanah puncak (PGA) di tanah permukaan.

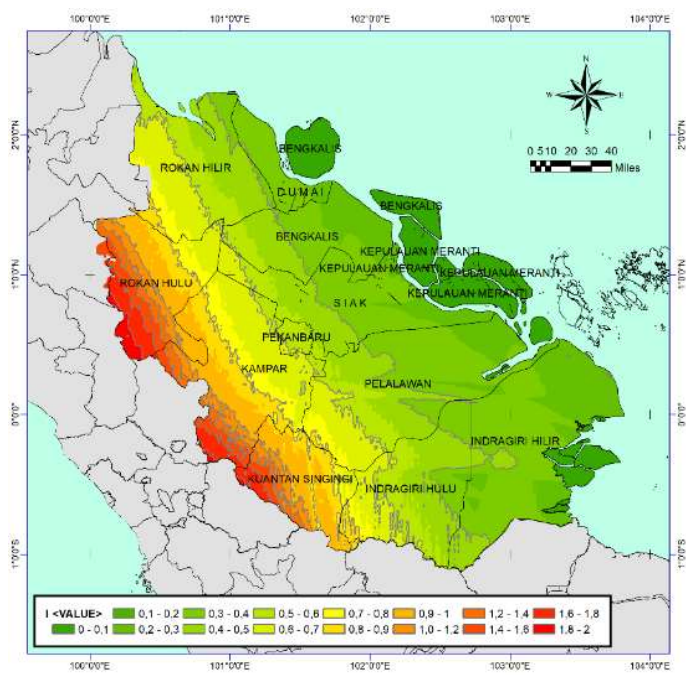

Gambar 7. Peta percepatan spektra 0.2 detik di tanah permukaan.

Kemudian pada percepatan spektra 0.2 detik dengan nilai percepatan tanah berada pada rentang $0.204-1.943 \mathrm{~g}$ dan yang terakhir pada percepatan spektra 1 detik nilai percepatan tanah permukaan berada pada rentang $0.176-1.155 \mathrm{~g}$.

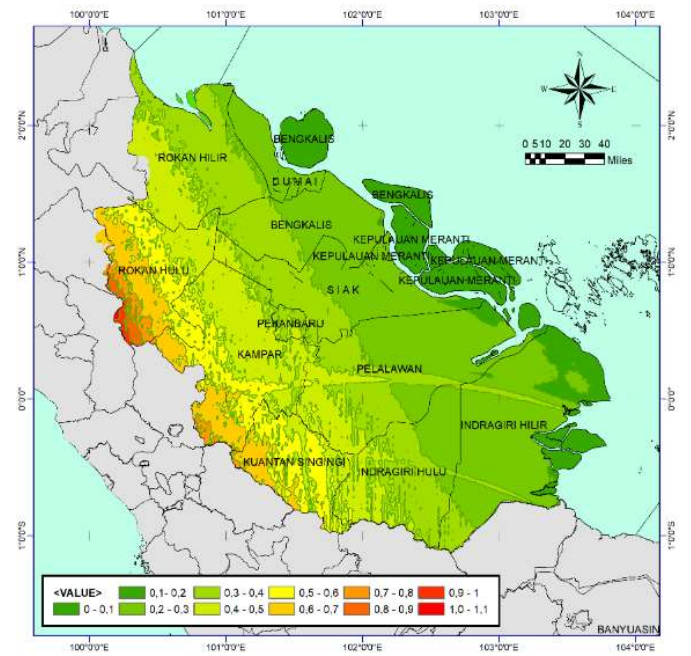

Gambar 8. Peta percepatan spektra 1 detik di tanah permukaan.

Nilai Percepatan Tanah Puncak di Permukaan Kabupaten/Kota Prov. Riau

Sebagaimana ditunjukkan dalam Gambar 9 dan Tabel 6, dari 12 kabupaten/kota yang ada di Provinsi Riau terdapat 3 kabupaten yang memiliki nilai percepatan tanah permukaan yang cukup tinggi, kabupaten yang dimaksud berturut-turut yaitu: Kabupaten Rokal Hulu, Kabupaten Kampar, dan Kabupaten Kuantan Singingi. Dilihat dari peta, 3 kabupaten tersebut merupakan kabupaten yang memiliki jarak paling dekat dengan sumber gempa, sehingga inilah yang menyebabkan 3 kabupaten ini memiliki nilai percepatan lebih tinggi dari 9 kabupaten lainnya. Sedangkan untuk kabupaten yang memiliki nilai percepatan tanah permukaan paling rendah ialah Kabupaten Kepulauan Meranti. Kabupaten ini merupakan kabupaten yang terpisah dari daratan kabupaten lainnya dan memiliki jarak paling jauh dengan sumber gempa, sehingga menyebabkan daerah ini memiliki nilai percepatan lebih kecil dan tidak beresiko terhadap ancaman gempa bumi. 


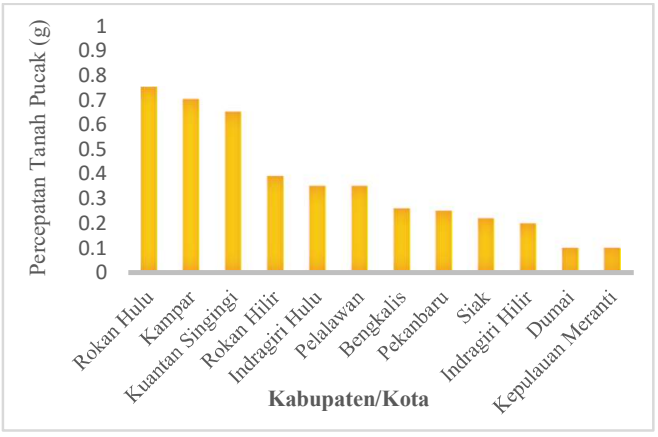

Gambar 9. Nilai percepatan tanah puncak (PGA) di permukaan

Tabel 6. Percepatan tanah puncak di permukaan tanah dengan probabilitas terlampaui $2 \%$ dalam 50 tahun

\begin{tabular}{|c|l|c|}
\hline No & \multicolumn{1}{|c|}{ Kabupaten/Kota } & Percepatan $(\mathrm{g})$ \\
\hline 1 & Bengkalis & $0,10-0,27$ \\
\hline 2 & Dumai & $0,10-0,18$ \\
\hline 3 & Kepulauan Meranti & $0,10-0,12$ \\
\hline 4 & Indragiri Hilir & $0,10-0,20$ \\
\hline 5 & Indragiri Hulu & $0,20-0,36$ \\
\hline 6 & Kampar & $0,24-0,72$ \\
\hline 7 & Pekanbaru & $0,22-0,27$ \\
\hline 8 & Kuantan Singingi & $0,34-0,62$ \\
\hline 9 & Pelalawan & $0,10-0,35$ \\
\hline 10 & Rokan Hilir & $0,20-0,40$ \\
\hline 11 & Rokan Hulu & $0,24-0,78$ \\
\hline 12 & Siak & $0,10-0,22$ \\
\hline
\end{tabular}

Seluruh wilayah Indonesia dinilai memiliki kerawanan gempa bumi kecuali pulau Kalimantan yang memiliki kerawanan relatif rendah. Kondisi ini membuat Indonesia harus memiliki upaya mitigasi yang kuat. Penataan ruang memiliki peranan besar dalam upaya mitigasi bencana, saat ini perencanaan tata ruang tidak hanya memetakan area pemukiman dan industri tetapi juga memetakan wilayah rawan bencana. Peta gempa 2017 yang dirilis oleh KemenPUPR masih bersifat makro atau nasional. Kebutuhan perencanaan tata ruang saat ini adalah skala mikro. Oleh karena itu peta gempa 2017 yang telah dirilis tersebut perlu dirincikan ke dalam peta mikrozonasi agar dapat implementasikan ke dalam Rencana Tata RuangWilayah (RTRW) dan Rencana Detail Tata Ruang (RDTR).

Hasil dari penelitian ini dapat dijadikan rujukan oleh pemerintah Provinsi Riau dalam perencanaan tata ruang berbasis mitigasi bahaya gempa, terutama pada kabupatenkabupaten yang memiliki risiko gempa cukup tinggi seperti Kabupaten Rokan Hulu, Kabupaten Kampar, dan Kabupaten Kuantan Singingi. Hasil dari penelitian ini dapat menjadi bahan pertimbangan oleh tiga pemerintah kabuapaten tersebut dalam merencanakan RTRW dan RDTR berbasis mitigasi bencana.

\section{KESIMPULAN}

Nilai percepatan tanah permukaan di Provinsi Riau pada percepatan tanah puncak (PGA) berada pada rentang $0.097-0,78 \mathrm{~g}$. kemudian pada periode 0.2 detik dengan nilai percepatan tanah berada pada rentang $0.204-$ $1.943 \mathrm{~g}$ dan pada periode 1 detik nilai percepatan tanah permukaan berada pada rentang $0.176-1.155 \mathrm{~g}$.

Kabupaten yang memiliki jarak lebih dekat dengan jalur Sesar Sumatera memiliki nilai percepatan lebih tinggi yaitu Kabupaten Rokan Hulu dengan percepatan maksimum sebesar 0.78 g, Kabupaten Kampar dengan percepatan maksimum $0.72 \mathrm{~g}$ dan Kabupaten Kuantan Singingi sebesar 0.62 g. Hasil penelitian ini mengindikasikan bahwa 3 kabupaten tersebut memiliki risiko gempa lebih tinggi dari kabupaten lainnya.

Dengan diperolehnya nilai percepatan tanah pada setiap kabupaten atau kota yang ada di Provinsi Riau, maka dapat dijadikan rujukan oleh pemerintah provinsi maupun pemerintah kabupatan dalam merencanakan pola tata ruang berbasis mitigasi bencana gempa.

\section{DAFTAR PUSTAKA}

Aki, K. (1965). "Maximum Likelihood Estimate of $\mathrm{b}$ in the formula $\mathrm{N}=\mathrm{a}-\mathrm{bm}$ and its Confidence Limits". Bulletin Earthquake Research Institute of the University of Tokyo, 43: 237-239.

Badan Nasional Penanggulangan Bencana. (2009). "Damage, Loss and Preliminary 
Needs Assessmen". Jakarta. Badan Nasional Penanggulangan Bencana.

Badan Geologi. (2018). “Di Balik Pesona Palu Bencana Melanda Geologi Menata". Bandung: Badan Geologi. ISBN: 978-602-9105-76-6.

Delfebriyadi. (2011). "Pengukuran Respok Spektra Kota Padang Menggunakan Metode Probabilitas". Jurnal Rekayasa Sipil, Vol. 7 No. 2, pp. 61-68.

Douglas. (2018). "Ground Motion Predictinon Equations 1964-2018". Departmen of Civil and Environmental Engineering, University of Stratchlyde.

Gardner, J.K. dan Knopoff, L. (1974). "Is the Sequence of Earthquakes in Southern California, with Aftershocks Removed, Poissonian?". Bulletin of the Seismological Society of America, Vol. 64, No. 5, 1363-1367.

Hadi. (2015). "Pemetaan Percepatan Getaran Tanah Maksimum Menggunakan Pendekatan Probabilistic Seismic Hazard Analysis (PSHA) di Kabupaten Kepahiang Provinsi Bengkulu”. Berkala Fisika. Vo. 18. No. 4, 101-112.

Makrup. (2013). "Seismic Hazard untuk Indonesia". Edisi Pertama, Graha Ilmu.

Makrup. (2009). "Pengembangan Peta Deagregasi Hazard untuk Indonesia Melalui Pembuatan Software dengan Pemodelan Sumber Gempa Tiga Dimensi”. Disertasi. Institut Teknologi Bandung.

Pusat Studi Gempa Nasional. (2017). "Peta Sumber dan Bahaya Gempa Indonesia Tahun 2017”. Badan Penelitian dan
Pengembangan Kementrian PUPR. ISBN 978-602-5489-01-3.

Rohadi, dkk. (2008). "Studi Potensi Seismotektonik Sebagai Precursor Tingkat Kegempaan di Wilayah Sumatera". Jurnal Meteorologi dan Geofisika, Vol. 9 No.2, $101-108$.

Suku, dkk. (2014). "Analisis Probabilitas Resiko Gempa (Probabilistic Seismic Hazard Analysis) Kota Ende Berdasarkan Fungsi Atenuasi JoynerBoore dan Youngs". Majalah Ilmiah Indikator. Vol. 18, No. 2, 01-18.

Sunardi. (2013). "Peta Deagregasi Hazard Gempa Wilayah Jawa dan Rekomendasi Ground Motion di Empat Daerah". Tesis, Universitas Islam Indonesia.

Thant, M. (2008). "Delineation of Strong Ground Motion by Using Aftershocks Data, Seismicity and Geological Information for Southern Yogyakarta Depression Area, Indonesia". Ph.D. Thesis. Faculty of Engineering, Gadjah Mada University. Yogyakarta

Widodo. (2012). "Seismologi Teknik dan Rekayasa Kegempaan”. Edisi Pertama, Pustaka Pelajar.

Widodo. (2018). "The Estimated PGA Map Of The Mw 6.42006 Yogyakarta Indonesia Earthquake, Constructed From The Modified Mercalli Intensity". Bulletin of the New Zealand Society for Earthquake Engineering, Vol. 51, No. 2, 92-104.

Wiemer, S. A. (2001). "Software Package to Analyze Seismicity: ZMAP". Seismological Research Letters. Vol.72, No. 3, 373-382. 